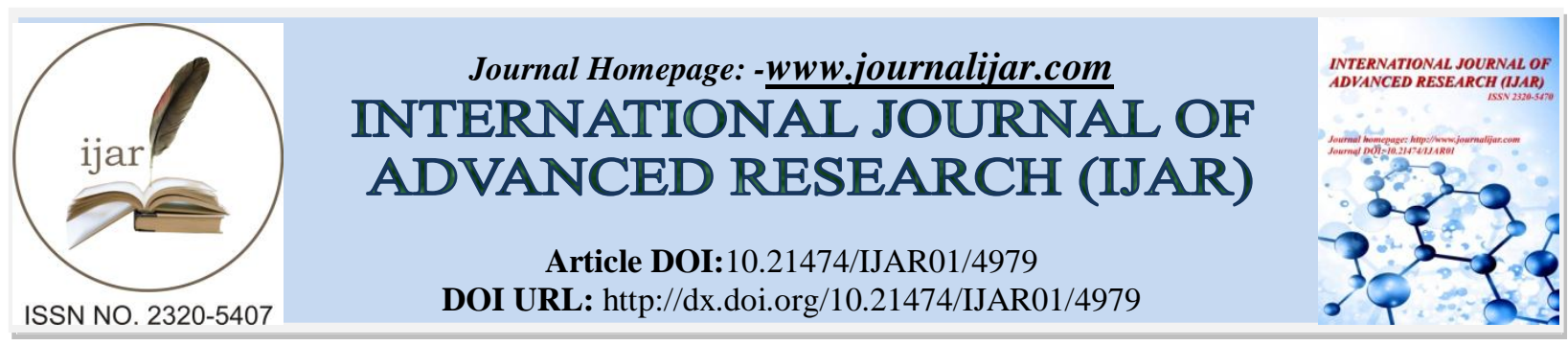

RESEARCH ARTICLE

\title{
JUNIPERUS COMMUNIS FORMATIONS ON HEATHS OR CALCAREOUS GRASSLAND - A NEW HABITAT IN THE DANUBIAN PLAIN (BULGARIA).
}

\author{
Dimcho Zahariev. \\ Faculty of Natural Sciences, Department of Plant Protection, Botany and Zoology, University of Shumen, Bulgaria.
}

\section{Manuscript Info}

Manuscript History

Received: 27 May 2017

Final Accepted: 29 June 2017

Published: July 2017

Key words:-

Juniperuscommunis, NATURA 2000,

protected areas, natural habitat,

conservation status, Danube Plain

\section{Abstract}

The natural habitat 5130 Juniperuscommunis formations on heaths or calcareous grasslandwas established for the first time in the Danube Plain (Northern Bulgaria).The habitat was found near the northern borders of the Shumen Plateau (The eastern part of the Danubian Plainin Republic of Bulgaria). So far such habitats have been discovered in the southern, western and central parts of Bulgaria. The presence of the habitat on the Shumen Plateau can be seen as an isolated example in comparison to its typical distribution in other areas. The new habitat is characterized by a rich composition of species typical for similar habitats. The locality differs from previously described localities of the habitat by its lower altitude, northwest-facing, small slope and low density of the phytocoenose of J. communis. The habitat was located within the Shumen Plateau Protected Area (BG0000382) and the Shumen Plateau Natural Park. The conservation status of the habitat in the protected area was assessed.

Copy Right, IJAR, 2017,. All rights reserved.

\section{Introduction:-}

Natural habitat 5130 Juniperuscommunis formations on heaths or calcareous grassland is announced by Council Directive 92/43/EEC on the Conservation of natural habitats and of wild fauna and flora, known as the Habitats Directive. In Bulgaria the conservation status of the habitat is potentially threatened (NT - A1, 2 B1 C1 D2 E2 F1 G1 H1 I L2). It is included in Appendix I of the Biodiversity Act of the Republic of Bulgaria and in the Red Data Book of the Republic of Bulgaria (Vitkova \& Tashev,2015).

This habitat type comprises the phytocoenoses of Common juniper (JuniperuscommunisL.) that occur throughout Bulgaria from the oak belt up to the mountain belt, and in some places reach the timberline (Central RhodopiMts). The species occurs in the subalpine belt as well, where it forms communities with VacciniummyrtillusL., and sometimes with $V$. vitis-idaeaL. The habitat usually develops on limestone terrains where soils are shallow and skeletal with frequent rock outcrops, and less moderately moist. It develops on eroded Cambisols and more rarely on Rendzic. This habitat covers mainly southern slopes, but sometimes occurs on western or eastern slopes as well. In most cases the slopes are steep, sometimes reaching 40 (Apostolova\&Meshinev, 2012a; Vitkova \& Tashev,2015). 
The phytocoenoses of $J$. communis have a two-layer structure, composed of a shrubs and woods layer and herbaceous layer. The horizontal structure is irregular. The projective cover varies considerably, from $30 \%$ up to 80\% (Apostolova\&Meshinev, 2012a; Vitkova \& Tashev,2015). Common juniper forms open communities in combination with xerophilous grass components characterized by a rich species composition. Common associated species are: Bothriochloa ischaemum(L.) Keng, Chrysopogon gryllus(L.) Trin., Bromus inermisLeyss., Festuca valesiacaSchleich. exGaudin, Carlina vulgarisL., Euphorbia cyparissiasL., Rosa spp., Salvia nemorosaL., Eryngium campestreL.etc. To identify the habitat, suffices to confirm the dominant presence of J.communis. The identification of other typically associated with it species is not necessary. The boundaries of the habitat are determined by the boundaries of distribution of the dominant species (Apostolova\&Meshinev, 2012a).

The habitat is in a relatively stable succession phase. Although of secondary origin, it remains stable over time. $J$. communismay increase its total projective cover, but this does not change the type of habitat. The onslaught of deciduous tree species is unlikely because of shallow and dry soils. A part of the habitat is used for grazing under restriction (Apostolova\&Meshinev, 2012a).

A threat to the habitat present the following: 1. Afforestation of land with artificial forest plantations - a moderate degree of threat; 2. Intensive grazing - a slight degree of threat; 3 . Fires - a moderate degree of threat (Apostolova\&Meshinev, 2012a). To these, we can add the following impacts: logging, collection of galbules for medicinal purposes, extention of the arable land, erosion, and soil-slides. The anthropogenic impact on the habitat used to be considerable in the past. A tendency for the restoration and the increase of the areas covered by Common juniper has been observed recently as a result of the abandonment of arable land (Vitkova \& Tashev,2015).

The area of the habitat at national level is 5054.73 ha (Apostolova\&Meshinev, 2012c). To protect the natural habitat, part of this area (993.94 ha) (Information system for Natura 2000 in Bulgaria)is included within the protected areas of the National Ecological Network of the Republic of Bulgaria, which is part of the European ecological network of protected areas NATURA 2000. The habitat spreads over 14 protected areas designated under the Habitats Directive: Vitosha (BG0000113), Sinitekamani (BG0000164), Lozenska Mt (BG0000165), DolniKoriten (BG0000295), Strandzha (BG0001007), Osogovska Mt (BG0001011), Oranovskiprolom - Leshko (BG0001022), SredenPirin - Alibotush (BG0001028), Rhodopi - Zapadni (BG0001030), Rhodopi - Sredni (BG0001031), Rhodopes - Iztochni (BG0001032), ZapadnaStaraplanina and Predbalkan (BG0001040), Yadenitsa (BG0001386), Srednagora (BG0001389) (Information system for Natura 2000 in Bulgaria). According to the latest data, such habitats are not anymore found in the other 4 protected areas where they were initially mapped: Krushe (BG0000626), Zemen (BG0001012), Popintsi (BG0001039) and Centralen Balkan-buffer (BG0001493).

\section{Materials and Methods:-}

This survey was conducted on the route method in July 2016. The marking of the range of the habitat was made using GPS receiver Garmin Oregon 450. WGS 84 UTM 35N coordinate system was used.

In determining the species was used the Handbook for Plants in Bulgaria (Delipavlov\& al., 2011). The names of the species are according to the Conspectus of the Bulgarian Vascular Flora (Asyov\& al., 2012). The abbreviations of the authors' names of the plants are according to the International Plant Names Index (IPNI 2015+). The families of flowering plants are according to the Angiosperm Phylogeny Group IV (2016).

The life forms are according to the Raunkiaer's system (Raunkiaer, 1934). For their determination were used the Flora of the People's Republic of Bulgaria (Yordanov, 1963-1979; Velchev, 1982-1989) and the Flora of the Republic of Bulgaria (Kozhuharov, 1995;Peev,2013). The projective cover of the species in the habitat is according to Braun-Blanquet (Westhoff \& Maarel, 1973). The assessment of the conservation status of the habitat in the protected area is according to the adopted methodology (Apostolova\&Meshinev, 2012b).

\section{Results and Discussion:-}

According to the current known data on the spread of the natural habitat (Apostolova\&Meshinev, 2012a; Vitkova \& Tashev,2015, Information system for Natura 2000 in Bulgaria), it occurs in southern, western and central parts of the Republic of Bulgaria (Fig. 1). The altitudinal range of the habitat is from 500 to $1900 \mathrm{~m}$ asl (Vitkova \& Tashev,2015). So far, there is no information about the discovery of the habitat in the Danube Plain (Northern part of the Republic of Bulgaria). 
As a result of fieldwork was found the habitat near the northern borders of the Shumen Plateau (quadrant MH99 in the eastern part of the Danubian Plain on the territory of the Republic of Bulgaria). As can be seen from Fig. 1, this part of the Danube Plain is hilly and characterized by plateaus. It can be assumed that what caused the habitat's spread here is the proximity to the hilly and low mountainous area known as Forebalkan that spreads south in the mountain range of the Balkan Mt. The distance between the new locality and Forebalkan is only $20 \mathrm{~km}$ by air in the south. The author thinks that this proximity provides only an explanation for the favorable conditions for the habitat, but does not sufficiently explain its origin. The author research in adjacent parts of the Forebalkan and the Balkan Mt did not yield other similar habitats. The nearest locality of another such habitat is near the town of Sliven about $75 \mathrm{~km}$ by air route in the southwest. The studies that the author have conducted in recent years in the neighbouring raised parts of the Danubian Plain, show a lack of such habitats in those locations. The presence of the habitat on the Shumen Plateau can be seen as an isolated example, because it is far away from typical for such habitats' areas. The habitat does not occur in lowland areas north of the Danube River in Romania, where there are no populations of $J$. communis (NATURA 2000 Standard Data Form for the Shumen Plateau Protected Area).

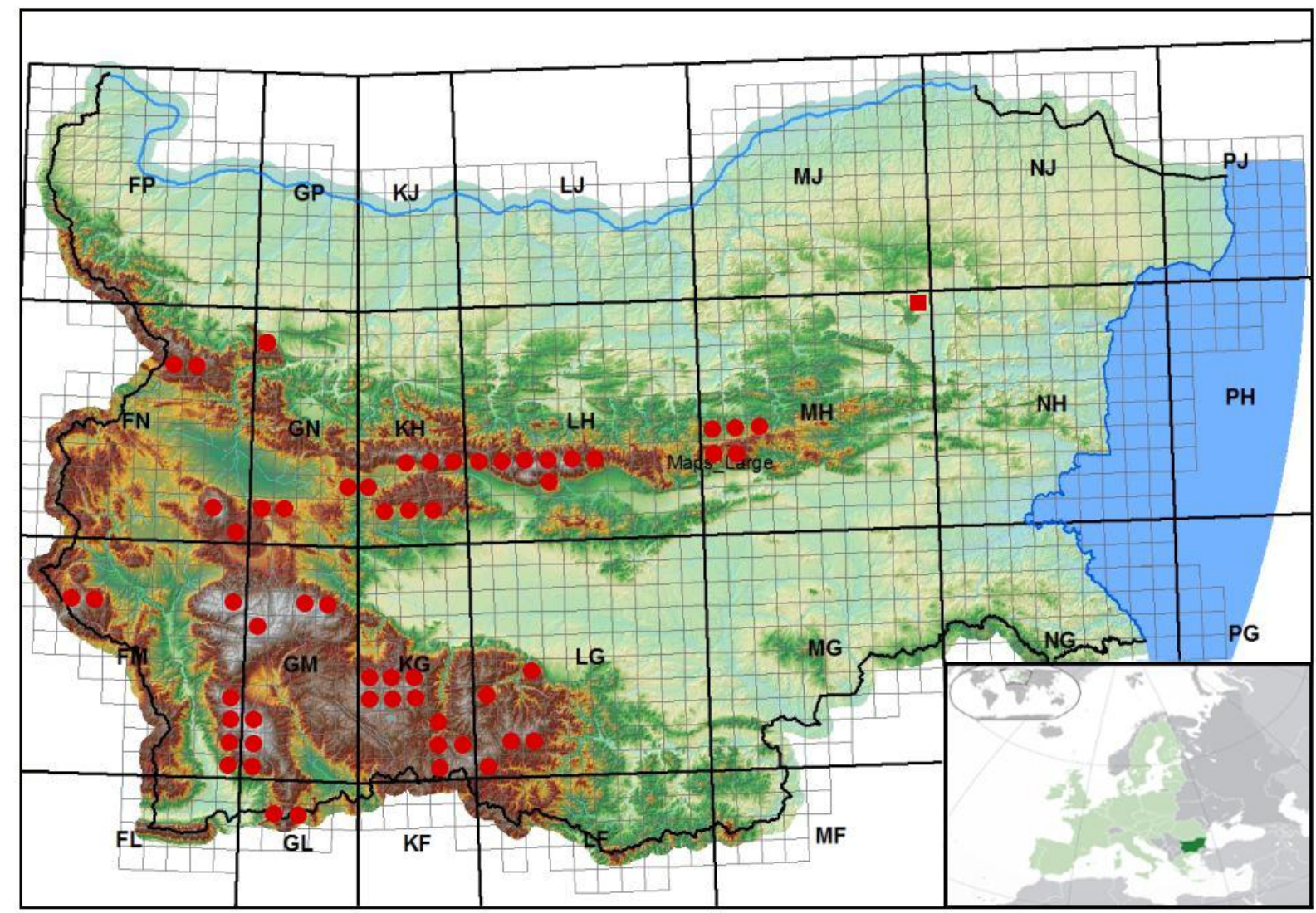

Figure 1:- Map of the distribution of the habitatin Bulgaria (modified after Vitkova\&Tashev 2015). Legend: circle known localities, box - new localityin quadrant MH99

The habitat that was established is located within the Shumen Plateau Protected Area (BG0000382) and Shumen Plateau Natural Park. So far, it has not been described in either the Standard Form of the protected area (NATURA 2000 Standard Data Form for the Shumen Plateau Protected Area), or in the Management Plan for the natural park (2011).

The habitat (Fig. 2) was located in three polygons (with area of 1.46 ha, 0.12 ha and 0.03 ha). The total area of the polygons is 1.61 ha. The coordinates of the endpoints of the range of the habitat are: $1.43 .298252^{\circ} \mathrm{N}, 26.886357^{\circ}$ $\mathrm{E} ; 2.43 .298091^{\circ} \mathrm{N}, 26.887069^{\circ} \mathrm{E} ; 3.43 .300380^{\circ} \mathrm{N}, 26.892313^{\circ} \mathrm{E} ; 4.43 .299201^{\circ} \mathrm{N}, 26.886225^{\circ}$ E. The altitude varies from 319 to $345 \mathrm{~m}$ asl. 
The exposure is northwest. The slope varies from $5^{\circ}$ to $10^{\circ}$ in individual polygons. The soil is shallow and it is a complex of lithocarbonaterendzinas and lithosols with calcareous rocks (Management plan for the Shumen Plateau Natural Park, 2011). The main rock is sandstone. The cover of the vegetation is $90 \%$ in the largest polygon.

The habitat borders on forest plantations of PinusnigraJ.F.Arnold. The floristic composition of the habitat occurs in the largest polygon (see Table in Appendix). In this habitat, were identified 78 species belonging to 70 genera and 28 families. Of these, 17 species are phanerophytes $(\mathrm{Ph}), 4$ species are chamaephytes $(\mathrm{Ch}), 54$ species are hemicryptophytes $(\mathrm{H}), 2$ species are cryptophytes $(\mathrm{Cr})$ and 1 species is a therophyte $(\mathrm{Th})$. The majority of the species -47 species $(60.3 \%)$ have a projective cover less than $5 \%$ and the number of individuals over 50 .

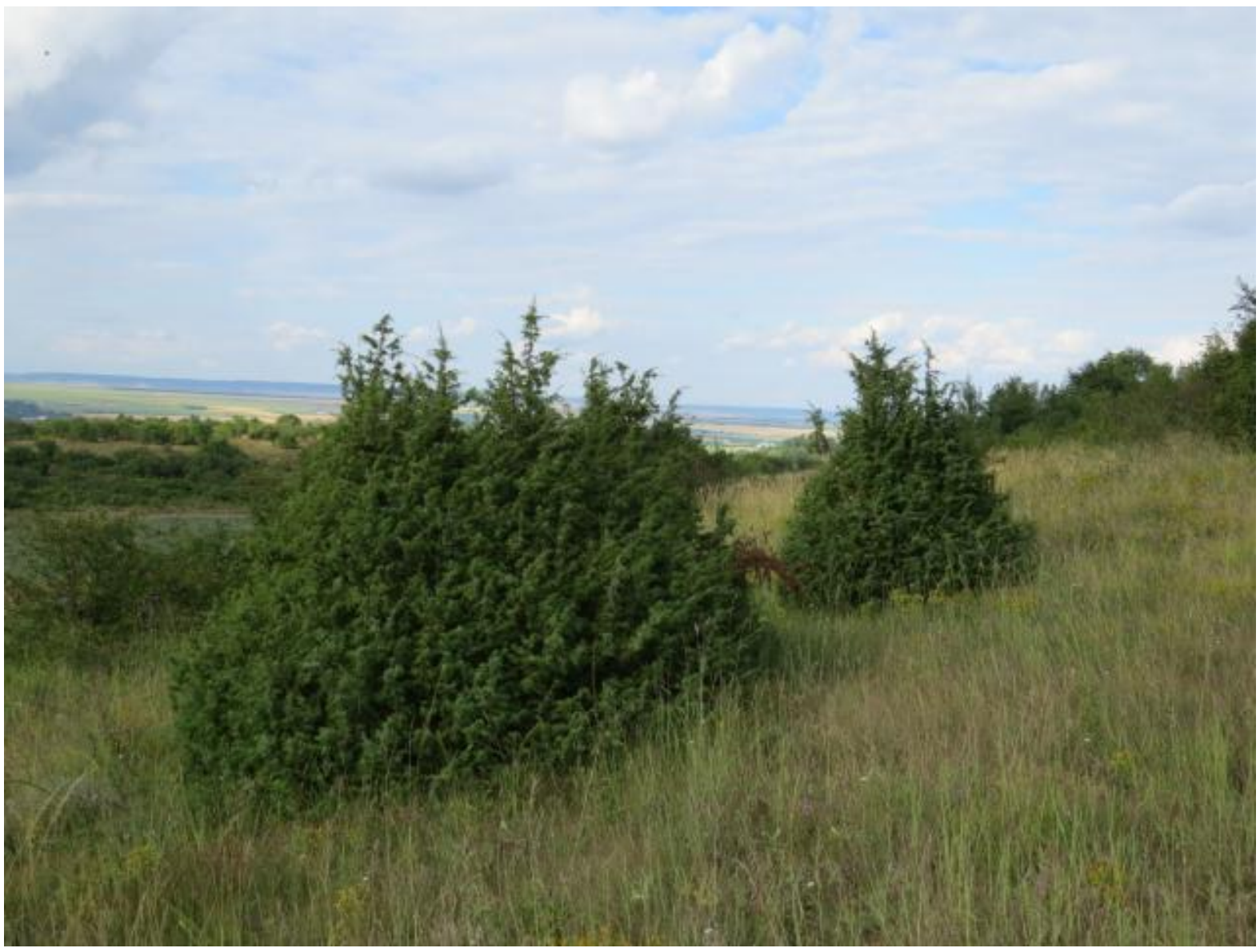

Figure 2:-A view at the habitat (Photograph by DimchoZahariev)

The assessment that was made on the habitat's conservation status in the Shumen Plateau Protected Area (BG0000382) follows the Methodology by Apostolova\&Meshinev (2012b) and reveals the following: According to Criterion 1 (The habitat's area within the protected area), the habitat is in favourable condition. This assessment is due to lack of information about reducing the area of the habitat. Since the habitat is established for the first time in the protected area, the present location was compared to the reference value from 2007 when the Shumen Plateau was decalred Protected Area. At that point, the habitat had not been registered and the reference value was assumed to be zero.

According to Criterion 2 (The habitat's structure and functions), the habitat is in unfavourable-bad condition. This assessment is based on a total of 7 parameters. If one of them demonstrates an unfavourable condition, the evaluation for all criterions is considered to be equal. Of the estimated parameters, six are in favourable condition and one is in unfavourable-bad condition. The results by individual parameters are as follows: 
1. Fragmentation within the habitat: The habitat's condition is favourable because there are no impacts which cause fragmentation.

2. Domination of J. communis: This parameter is in unfavourable-bad condition. The reason is that less than $25 \%$ of the habitat is covered by the population of J. communis.

3. Summary projective coverage of the phytocenoses: The condition of the habitat is favourable because the cumulative projective coverage of phytocenoses exceeds the required minimum of $60 \%$.

4. Typical plant species: The condition of the habitat is favourable. To identify the habitat, the dominant presence of $J$. communis suffices. Furthermore, was described a sufficient number of typical plants for the habitat: Bothriochloaischaemum(L.) Keng,Carlina vulgaris L.,CrataegusmonogynaJacq., Eryngiumcampestre L., JuniperuscommunisL., Plantago media L., Rosaspp.

5. Ruderalisation and secondary increase on tree and shrub species within the habitat in result of converting to mesophilic conditions or transfering of biogenes from neighbouring arable lands: The condition of the habitat is favourable because the ruderal species do not form separate cenoses and bushes and trees do not increase.

6. Presence of invasive species: The condition of the habitat is favourable due to lack of invasive species.

7. Resumption of J. communis: The condition of the habitat is favourable, because the population of J. communis is resumed. Proof of this is the presence of individuals of different ages. There are dozens of young individuals.

According to Criterion 3 (Future Prospects - threats and influences), the habitat is in unfavourable-bad condition. The formation of this assessment took into account three criteria:

1. Intensity of grazing: The condition is unfavourable-bad due to complete absence of grazing.

2. Use of fertilizers and pesticides and presence of contaminants (importers of biogenes): The habitat is in unfavourable-bad condition due to availability of arable land within a radius of less than $100 \mathrm{~m}$ away from the habitat. The arable areas are associated with the use of fertilizers and pesticides and the transfer of weed species. In this research were found the presence of a small number of weed species (Euphorbia agrariaM.Bieb.,Rubuscaesius L.,SambucusebulusL.) with a total projective cover less than 5\%.

3. Fires: The condition of the habitat is favourable because in its territory and in the vicinity have not been registered any fires.

The overall assessment of the natural habitat's state according to the three criteria is unfavourable-bad condition. The reason for this is the assessment according to 3 parameters as described in the second and third criteria above.

The unique location of the habitat requires taking measures to improve its conservation status. These measures are the following:

1. Increasing the density of the population of J. communis. The natural increase in the number, which was found in this study, can be supported by seed propagation. The seed material must come from the local population in order to protect its gene pool.

2. Motivating local shepherds to hold moderate intensity grazing within the habitat. According to the methodology the number of animals should be 0.3-1.5 animals of 1 ha. Grazing should be held in no less than $90 \%$ of the area of habitat.

3. Growing that does not require the use of fertilizers and pesticides in the arable land within a radius of 100 meters of the habitat can grow crops. At worst, they may be replaced with meadows.

\section{Conclusion:-}

The natural habitat 5130 Juniperuscommunis formations on heaths or calcareous grasslandis a new habitat in the Danubian Plain (Northern Bulgaria). It is characterized by a rich species composition that is typical for such habitats. The locality differs from the previously described localities of the habitat in the following: lower altitude, northwest-facing, small slope and low density of the phytocoenose of J. communis. The author propose to adjust the altitude range of the habitat's distribution as the lower limit needs to be changed from the current $500 \mathrm{~m}$ asl to the more accurate $320 \mathrm{~m}$ asl. In order to improve the conservation status of the habitat, the authorsuggest taking adequate measures.

\section{Appendix:-}

Table 1:-Floristic composition of the habitat

Legend: $2 \mathrm{a}$ - projective cover from 5 to $12.5 \%, 2 \mathrm{~m}$ - projective cover less than $5 \%$ and number over 50 individuals, 1 - projective cover less than 5\% and number among 6 and 50 individuals, +- projective cover less than $5 \%$ and number among 2 and 5 individuals, $r$ - projective cover less than $5 \%$ and only one individual. 


\begin{tabular}{|c|c|c|c|c|}
\hline No & Plant name & Family & Life form & $\begin{array}{c}\text { Projective } \\
\text { cover }\end{array}$ \\
\hline 1 & JuniperuscommunisL. & Cupressaceae & $\mathrm{Ph}$ & $2 \mathrm{a}$ \\
\hline 2 & Botriochloaischaemum (L.) Keng & Poaceae & $\mathrm{H}$ & $2 \mathrm{a}$ \\
\hline 3 & Brachypodiumpinnatum(L.) P.Beauv. & Poaceae & $\mathrm{H}$ & $2 \mathrm{a}$ \\
\hline 4 & PinusnigraJ.F.Arnold & Pinaceae & $\mathrm{Ph}$ & $2 \mathrm{a}$ \\
\hline 5 & PoatrivialisL. & Poaceae & $\mathrm{H}$ & $2 \mathrm{a}$ \\
\hline 6 & Ulmus minor Mill. & Ulmaceae & $\mathrm{Ph}$ & $2 \mathrm{a}$ \\
\hline 7 & Achilleamillefolium $\mathrm{L}$. & Asteraceae & $\mathrm{H}$ & $2 \mathrm{~m}$ \\
\hline 8 & Agrimoniaeupatoria $\mathrm{L}$. & Rosaceae & $\mathrm{H}$ & $2 \mathrm{~m}$ \\
\hline 9 & Anacamptispyramidalis (L.) Rich. & Orchidaceae & $\mathrm{Cr}$ & $2 \mathrm{~m}$ \\
\hline 10 & Anthyllisvulneraria $\mathrm{L}$. & Fabaceae & $\mathrm{H}$ & $2 \mathrm{~m}$ \\
\hline 11 & Arrhenatherumelatius (L.) P.Beauv. ex J.Presl\&C.Presl & Poaceae & $\mathrm{H}$ & $2 \mathrm{~m}$ \\
\hline 12 & Asperulacynanchica $\mathrm{L}$. & Rubiaceae & $\mathrm{H}$ & $2 \mathrm{~m}$ \\
\hline 13 & AstragalusonobrychisL. & Fabaceae & $\mathrm{H}$ & $2 \mathrm{~m}$ \\
\hline 14 & BrachypodiumsylvaticumP.Beauv. & Poaceae & $\mathrm{H}$ & $2 \mathrm{~m}$ \\
\hline 15 & Briza media $\mathrm{L}$. & Poaceae & $\mathrm{H}$ & $2 \mathrm{~m}$ \\
\hline 16 & Campanula rapunculoides $\mathrm{L}$. & Campanulaceae & $\mathrm{H}$ & $2 \mathrm{~m}$ \\
\hline 17 & CarexflaccaSchreb. & Cyperaceae & $\mathrm{H}$ & $2 \mathrm{~m}$ \\
\hline 18 & Carlinaacanthifolia All. & Asteraceae & $\mathrm{H}$ & $2 \mathrm{~m}$ \\
\hline 19 & Carlina vulgaris $\mathrm{L}$. & Asteraceae & $\mathrm{H}$ & $2 \mathrm{~m}$ \\
\hline 20 & CentaurearhenanaBoreau & Asteraceae & $\mathrm{H}$ & $2 \mathrm{~m}$ \\
\hline 21 & Centaureascabiosa L. & Asteraceae & $\mathrm{H}$ & $2 \mathrm{~m}$ \\
\hline 22 & Clinopodiumvulgare $\mathrm{L}$. & Lamiaceae & $\mathrm{H}$ & $2 \mathrm{~m}$ \\
\hline 23 & Cornussanguinea $\mathrm{L}$. & Cornaceae & $\mathrm{Ph}$ & $2 \mathrm{~m}$ \\
\hline 24 & Coronillavaria $\mathrm{L}$. & Fabaceae & $\mathrm{H}$ & $2 \mathrm{~m}$ \\
\hline 25 & CrataegusmonogynaJacq. & Rosaceae & $\mathrm{Ph}$ & $2 \mathrm{~m}$ \\
\hline 26 & Cuscutaepithymum L. & Convolvulaceae & Th & $2 \mathrm{~m}$ \\
\hline 27 & Dactylisglomerata L. & Poaceae & $\mathrm{H}$ & $2 \mathrm{~m}$ \\
\hline 28 & Dorycniumherbaceum Vill. & Fabaceae & $\mathrm{Ch}$ & $2 \mathrm{~m}$ \\
\hline 29 & Eryngiumcampestre L. & Apiaceae & $\mathrm{H}$ & $2 \mathrm{~m}$ \\
\hline 30 & Euphorbia agrariaM.Bieb. & Euphorbiaceae & $\mathrm{H}$ & $2 \mathrm{~m}$ \\
\hline 31 & Euphorbia amygdaloidesL. & Euphorbiaceae & $\mathrm{H}$ & $2 \mathrm{~m}$ \\
\hline 32 & Filipendula vulgaris Moench & Rosaceae & $\mathrm{H}$ & $2 \mathrm{~m}$ \\
\hline 33 & Fragariavesca $\mathrm{L}$. & Rosaceae & $\mathrm{H}$ & $2 \mathrm{~m}$ \\
\hline 34 & Galium album Mill. & Rubiaceae & $\mathrm{H}$ & $2 \mathrm{~m}$ \\
\hline 35 & Hypericumperforatum $\mathrm{L}$. & Hypericaceae & $\mathrm{H}$ & $2 \mathrm{~m}$ \\
\hline 36 & KnautiamacedonicaGriseb. & Caprifoliaceae & $\mathrm{H}$ & $2 \mathrm{~m}$ \\
\hline 37 & KoeleriasimonkaiiAdamovič & Poaceae & $\mathrm{H}$ & $2 \mathrm{~m}$ \\
\hline 38 & Lembotropisnigricans(L.) Griseb. & Fabaceae & $\mathrm{Ph}$ & $2 \mathrm{~m}$ \\
\hline 39 & LeontodoncrispusVill. & Asteraceae & $\mathrm{H}$ & $2 \mathrm{~m}$ \\
\hline 40 & Leucanthemumvulgare Lam. & Asteraceae & $\mathrm{H}$ & $2 \mathrm{~m}$ \\
\hline 41 & LinumtenuifoliumL. & Linaceae & $\mathrm{H}$ & $2 \mathrm{~m}$ \\
\hline 42 & MedicagofalcataL. & Fabaceae & $\mathrm{H}$ & $2 \mathrm{~m}$ \\
\hline 43 & Ononisspinosa L. & Fabaceae & $\mathrm{Ch}$ & $2 \mathrm{~m}$ \\
\hline 44 & Origanumvulgare L. & Lamiaceae & $\mathrm{Ch}$ & $2 \mathrm{~m}$ \\
\hline 45 & Plantago media L. & Plantaginaceae & $\mathrm{H}$ & $2 \mathrm{~m}$ \\
\hline 46 & Polygala major Jacq. & Polygalaceae & $\mathrm{H}$ & $2 \mathrm{~m}$ \\
\hline 47 & PrunusspinosaL. & Rosaceae & $\mathrm{Ph}$ & $2 \mathrm{~m}$ \\
\hline 48 & Pyruspyraster(L.) Burgsd. & Rosaceae & $\mathrm{Ph}$ & $2 \mathrm{~m}$ \\
\hline 49 & Sanguisorba minor Scop. & Rosaceae & $\mathrm{H}$ & $2 \mathrm{~m}$ \\
\hline 50 & ScabiosaochroleucaL. & Caprifoliaceae & $\mathrm{H}$ & $2 \mathrm{~m}$ \\
\hline 51 & Silene vulgaris (Moench) Garcke & Caryophyllaceae & $\mathrm{H}$ & $2 m$ \\
\hline 52 & Teucriumchamaedrys L. & Lamiaceae & $\mathrm{Ph}$ & $2 \mathrm{~m}$ \\
\hline
\end{tabular}




\begin{tabular}{|c|c|c|c|c|}
\hline 53 & Thymus callieriHalácsy ex Litv. & Lamiaceae & $\mathrm{Ch}$ & $2 \mathrm{~m}$ \\
\hline 54 & Ajugalaxmanii(L.) Benth. & Lamiaceae & $\mathrm{H}$ & 1 \\
\hline 55 & Allium rotundumL. & Amaryllidaceae & $\mathrm{Cr}$ & 1 \\
\hline 56 & Campanula sibirica $\mathrm{L}$. & Campanulaceae & $\mathrm{H}$ & 1 \\
\hline 57 & Cichoriumintybus L. & Asteraceae & $\mathrm{H}$ & 1 \\
\hline 58 & Clematis vitalba $\mathrm{L}$. & Ranunculaceae & $\mathrm{Ph}$ & 1 \\
\hline 59 & Cornus mas L. & Cornaceae & $\mathrm{Ph}$ & 1 \\
\hline 60 & Cotatinctoria (L.) J.Gay. & Asteraceae & $\mathrm{H}$ & 1 \\
\hline 61 & Daucuscarota L. & Apiaceae & $\mathrm{H}$ & 1 \\
\hline 62 & Dianthus giganteus D'Urv. & Caryophyllaceae & $\mathrm{H}$ & 1 \\
\hline 63 & Digitalis lanataEhrh. & Scrophulariaceae & $\mathrm{H}$ & 1 \\
\hline 64 & HieraciumcymosumL. & Asteraceae & $\mathrm{H}$ & 1 \\
\hline 65 & KnautiadrymeiaHeuff. & Caprifoliaceae & $\mathrm{H}$ & 1 \\
\hline 66 & Ligustrumvulgare L. & Oleaceae & $\mathrm{Ph}$ & 1 \\
\hline 67 & PotentillapedataWilld. & Rosaceae & $\mathrm{H}$ & 1 \\
\hline 68 & RanunculusvelutinusTen. & Ranunculaceae & $\mathrm{H}$ & 1 \\
\hline 69 & Rosa caninaL. & Rosaceae & $\mathrm{Ph}$ & 1 \\
\hline 70 & Rubuscaesius L. & Rosaceae & $\mathrm{Ph}$ & 1 \\
\hline 71 & SambucusebulusL. & Caprifoliaceae & $\mathrm{H}$ & 1 \\
\hline 72 & TragopogondubiusScop. & Asteraceae & $\mathrm{H}$ & 1 \\
\hline 73 & VincetoxicumhirundinariaMedik. & Apocynaceae & $\mathrm{H}$ & 1 \\
\hline 74 & Juglansregia L. & Juglandaceae & $\mathrm{Ph}$ & + \\
\hline 75 & Thalictrum minus L. & Ranunculaceae & $\mathrm{H}$ & + \\
\hline 76 & Viburnum lantana $\mathrm{L}$. & Caprifoliaceae & $\mathrm{Ph}$ & + \\
\hline 77 & PicrishieracioidesL. & Asteraceae & $\mathrm{H}$ & $\mathrm{r}$ \\
\hline 78 & PinussylvestrisL. & Pinaceae & $\mathrm{Ph}$ & $\mathrm{r}$ \\
\hline
\end{tabular}

\section{References:-}

1. Act on Amending and Supplementing the Biological Diversity Act of the Republic of Bulgaria. Annex I. State Gazette number 94, 16 November 2007.

2. Angiosperm Phylogeny Group (2016): An update of the Angiosperm Phylogeny Group classification for the orders and families of flowering plants: APG IV.Bot. J. Linn. Soc. 181: 1-20.

3. Apostolova, I. andMeshinev, T. (2012a): Methodology for mapping the distribution of natural habitat 5130 Juniperus communis formations on heaths or calcareous grassland, $29 \mathrm{p}$.

4. Apostolova, I. andMeshinev, T. (2012b): Methodology for determining the conservation status of natural habitat 5130 Juniperus communis formations on heaths or calcareous grassland, $37 \mathrm{p}$.

5. Apostolova, I. andMeshinev, T. (2012c): National evaluations and reference values for favorable conservation status of natural habitat 5130 Juniperus communis formations on heaths or calcareous grassland, $4 \mathrm{p}$.

6. Asyov, B., Petrova, A., Dimitrov, D.and Vasilev, R. (2012): Conspectus of the Bulgarian vascular flora. Distribution maps and floristic elements.Bulgarian Biodiversity Foundation, Sofia, 489p.

7. Council Directive 92/43/EEC of 21 May 1992 on the Conservation of Natural Habitats and of Wild Fauna and Flora, Annex I. OJ L 206, 22.07.1992.

8. Delipavlov, D., Cheshmedzhiev, I., Popova, M., Terziiski, D. and Kovachev, I. (2011): Handbook for Plants in Bulgaria, Publishing House of Agricultural University, Plovdiv,591 p.

9. Information system for Natura 2000 in Bulgaria, Ministry of Environment and Water. Published at http://natura2000.moew.government.bg [accessed 24June 2017].

10. IPNI 2015+ [continuously updated]: The International Plant Names Index. Published at http://www.ipni.org [accessed 24 June2017].

11. Jalas, J.and Suominen, J.(eds.) (1973): Atlas Florae Europaeae. Distribution of Vascular Plants in Europe. 2. Gymnospermae (Pinaceae to Ephedraceae). The Committee for Mapping the Flora of Europe \& Societas Biologica Fennica Vanamo, Helsinki,Helsinki Univ. Printing House, 40 p.

12. Kozhuharov, S. (ed.) (1995): Flora of the Republic of Bulgaria, vol. 10, Prof. M. Drinov Acad. Publ., Sofia, 428 p.

13. Management plan for the Shumen Plateau Natural Park, 2011, 211 p. 
14. NATURA 2000 Standard Data Form for the Shumen Plateau Protected Area (BG0000382), Ministry of Environment and Water, $13 \mathrm{p}$.

15. Peev, D. (ed.) (2013): Flora of the Republic of Bulgaria, vol. 11, Prof. M. Drinov Acad. Publ., Sofia, 523 p.

16. Raunkiaer, C.(1934): The Life forms of plants and statistical plant geography, Clarendon Press, Oxford, 147 p.

17. Velchev, V. (ed.)(1982-1989): Flora of PR Bulgaria, vol. 8-9, Publishing House of BAS, Sofia.

18. Vitkova, A.and Tashev, A. (2015):17F3 Hrastalaciotsinyahvoyna(Juniperus communis)[17F3 Common juniper (Juniperus communis) scrub],pp.241-242, In: Biserkov, V.(main ed.)Red Data Book of Republic of Bulgaria3. Natural Habitats. Sofia, BAS \& MOEW.

19. Westhoff, V.and Maarel, E. (1973): The Braun-Blanquet Approach.pp. 619-704,In: Tuxen, R. (ed.), Handbook of vegetation science. Hague, Dr. W. Junk b. v. Publishers.

20. Yordanov, D. (main ed.)(1963-1979): Flora of PR Bulgaria, vol. 1-7, Publishing House of BAS, Sofia. 